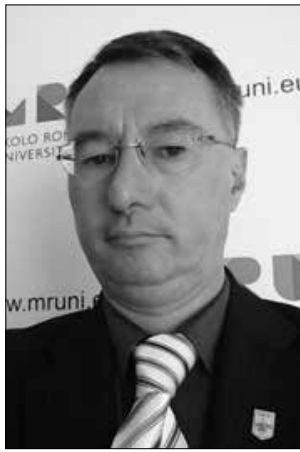

https://doi.org/10.24101/logos.2017.72

\title{
VLADISLAV B. SOTIROVIĆ
}

Mykolas Romeris University, Lithuania

Mykolo Romerio universitetas, Lietuva

\section{THE IDEA OF A GREATER (UNITED) CROATIA BY PAVAO RITTER VITEZOVIĆ: AN EARLY-MODERN MODEL OF THE NATIONAL IDENTITY AND CREATION OF THE NATIONAL STATE OF THE CROATO-SLAVS}

Pavao Ritterio Vitezovićiaus Didžiosios (Jungtinės) Kroatijos idėja: ankstyvasis modernus nacionalinès tapatybès modelis ir nacionalinės kroatų-slavų valstybès kūrimas

\section{SANTRAUKA}

Straipsnyje nagrinejjamas kroatų didiko publicisto ir istoriko Pavao Ritterio Vitezovićiaus (1652-1713) „Didžiosios Kroatijos" modelis. Daugelis istorikų tyrinėjo Vitezovićiaus politines mintis ir jo išplètotą vieningos Pietų Slavų valstybės, kaip platesnio vieningo Slavų pasaulio dalies, ideologinę sistemą. Pasak vyraujančio mokslininkų požiūrio, Vitezovićius buvo „jugoslavizmo” (suvienytos Pietų Slavų tautinės valstybès) ir netgi vieningo slavizmo, vieningo slavų kultūrinio ir politinio abipusiškumo idèjos pirmtakas. Jo amžininkų tekstuose siūlomas alternatyvus būdas apibrèžti modernių Pietų Slavų etninių valstybių sienas. Vitezovićius siekè kurti kroatų nacionalinę valstybę remiantis pastangomis konsoliduoti kroatų „etnines teritorijas" ir "etnolingvistines linijas". Šios tapatybės sampratos analizè atskleidžia, kaip buvo suprastos numatytos ankstyvosios modernios kroatų etninès valstybès sienos. Ji apima plačias teritorijas nuo Adrijos jūros iki Maskvos ir nuo Baltijos jūros iki Juodosios jūros. Vitezovićiaus požiūris i lietuvius ir LenkijosLietuvos Sąjungą liudija, kad argumentas, kuriuo grindžiami jo reikalavimai Kroatijos tautinei valstybei, paremtas etnolingvistine giminyste. 


\section{SUMMARY}

The paper will examine the model for the creation of a 'Greater Croatia' designed by the Croatian noblemen, publicist and historian Pavao Ritter Vitezović (1652-1713). Many historians have viewed Vitezović's political thought and his developed ideological framework of a united South Slavic state as part of a wider pan-Slavic world. According to the prevailing notion, Vitezović was a precursor of the idea of ' $Y u$ goslavism' (a united Southern Slav nation state) and even 'Pan-Slavism', a pan-Slavic cultural and political reciprocity. Yet a closer look at Vitezović and his contemporaries' writings suggests an alternative model for outlining the borders of modern ethnic states among the Southern Slavs. Vitezović argued for the creation of a Croat national state, based on the integration of the Croat 'ethnic territories' and their consolidation along ethno-linguistic lines. The analysis of Vitezović's understanding of nationhood explains how the borders of an envisioned early modern Croat ethnic state had been perceived as including vast territories from the Adriatic Sea to Moscow and from the Baltic Sea to the Black Sea. In this respect Vitezović's views on the Lithuanians and the Polish-Lithuanian Commonwealth will show that the argument used to substantiate his claims for a Croatian nation state was based on an ethno-linguistic kinship.

C ontemporary historiography and the Slavonic studies upon the question of ethnolinguistic origin of the Croats and the Serbs more and more incline on the side of those authors who support the linguistic theory of the Indo-Sarmatian (the Iranian) origins of proto-Croats and proto-Serbs. According to this contemporary explanation, "Croats" and "Serbs" were the people of the Iranian (the Sarmatian) origin, who migrated into the Balkans in the $7^{\text {th }}$ century and subjected the Slavs there. However, in the course of time, they became totally Slavizied (like proto-Turkic Bulgars who were settled on the Balkans between the Danube River and the Balkan Range), but gave their own ethnic name to the Balkan Slavic subjects. At least from the beginning of the $9^{\text {th }}$ century both "Croats" and "Serbs" are clearly a Slavic people. For those authors, linguists proved that words Croat and Serb are not of the Slavic language at all. They believe that name "Croat" is similar to the Iranian-Sarmatian place name "Choroathos", on the lower Don River, or that name "Croat" originated in the Iranian
"Chrovatosa", a prominent chieftain who gave his own personal name to the tribe (people) ruled by him.

Some scholars argue that the Iranian name "Croat" can be found as a personal name in the inscriptions from Tanais from the $2^{\text {nd }}$ and $3^{\text {rd }}$ centuries, or that words "haurvatar" means in Iranian - "cattle-breeder", and "huurvatha" "friend". In addition, there are two Greek inscriptions in the area of the Azov Sea around the mouth of the Don River related to the personal names "Horóathos" and "Horúathos", which are considered to be of the Iranian-Sarmatian origin. Around the time of Jesus Christ, there was the Iranian-Sarmatian tribe on the lower Don River that was known to the Greek geographers as "Serboi". In the $10^{\text {th }}$ century one Arab geographer noted a "Sarban" tribe in the Caucasus. These two tribes are clearly not of the Slavic origin.

As a matter of fact, many ethnic Slavs have participated in the armies led by the Iranian-Sarmatian "Croats" and "Serbs" and have migrated to the Balkans with their Iranian-Sarmatian military leaders 
and lords. Assimilation, i.e. Slavization, of the Iranian-Sarmatian "Croats" and "Serbs" started already beyond the Carpathian Mountains. The Iranian-Sarmatian "Croats" and "Serbs" have been relatively few in number, but as warrior horsemen they became greatly superior over conquered Slavs. They came to the Balkans in the second wave of the Slavic settlement on the peninsula where they met and subjugated already settled Slavic tribes from the first wave of migration to the Balkans. The newcomers, led by the Iranian-Sarmatian "Croats" and "Serbs", provided a general name for all Slavs under their sway, which are known today as the ethnic Croats and Serbs. In the other words, since the Slavs were the vast majority, and as the Iranian-Sarmatian "Croats" and "Serbs" intermarried and mixed with them, in the course of time the conquerors came to speak Slavic too and ultimately the Slavic language they came to speak and which had been spoken by the earlier arriving Slavs (from the first migration) came to be named after the Iranian-Sarmatian newcomers (from the second migration to the Balkans). Finally, this process of assimilation was identical with that one of the Turkic Bulgars who conquered the Slavic tribes on the territory of the present-day North Bulgaria. They came to be Slavizied in the course of time, but provided the ethnic name for the Slavic people, language, and state established in Bulgaria (Gregoire 1944-1945: 88-118; Conte 1986: 300; Fine 1994: 49-59, 305-307; Macan 1992: 15; Ćorović 1993: 49-50; compare with Davies 1981: 45).

\section{IMPORTANCE AND INFLUENCE OF VITEZOVIĆ'S IDEOLOGICAL CONCEPT}

P. R. Vitezović's works had a great impact on development of the South Slavic national ideologies, national consciousness and nationalism. Paradoxically but true, Vitezović influenced at the great degree the $18^{\text {th }}$ century Serbian and Bulgarian national movements. His heraldic manual under the title Stemmatographia, sive Armorum Illyricorum delineatio, descriptio et restitution (Vienna, 1701), in which coats of arms of all "Illyrian" (i.e., according to him, Croatian) historical provinces were presented, was translated into the Slavonic-Serbian language, adapted and expanded in the mid- $18^{\text {th }}$ century by the Serbian patriot of the Bulgarian ethnic origin from the South Hungary, Hristifor Žefarović (1700-1753). Nonetheless, pre- viously to Vitezović, the examples of coats of arms of Illyria (i.e. the Balkans) were available in Sebastian Münster's Cosmographia (Basel, 1544) and revised by the Italian version in 1575. A very idea of the Illyrian (i.e. the Balkan or the South Slavic) unity could be found exactly in the Münster's Cosmographia, where the lands of Carinthia, Carniola, Croatia, Slavonia and Bosnia-Herzegovina are described as the Illyrian provinces.

P. R. Vitezović used, in addition to S. Münster's Cosmographia, as a basis for his own armorial manual, a heraldic work of the Herzegovinian nobleman and admiral in the Spanish navy service, Petar Ohmučević (known in Spain as Don Pedro) from 1596. Ohmučević's version of 
united Pan-Illyrian Empire of Stefan Dušan Almighty (a Serbian ruler from 1331 to 1355) was illustrated by coats of arms of the following "Illyrian" lands: Macedonia, Bosnia, Dalmatia, Croatia, Slavonia, Bulgaria, Serbia, Rascia and Littoral. Ohmučević's armorial manual was used and extended by Mavro Orbin from Dubrovnik in his famous work where coats of arms of Bulgaria, Slavonia, Bosnia, Macedonia, Dalmatia, Serbia, Croatia, Rascia and Littoral were considered as historical provinces of the South Slavic Empire of Stefan Dušan who was the most famous, mighty and glorified South Slavic ruler as the Emperor of Serbia from 1346 to 1355 (Banac 1993: 218-225). ${ }^{12}$ Nevertheless, in Vitezović's interpretation, all of these coats of arms were heraldic insignias of the Croatian historical and ethnolinguistic provinces. These insignias were followed in Vitezovićs armorial work by the next arms of the Croatian lands: Bohemia, Muscovy, Poland-Lithuanian Republic, Ukraine, Carinthia, Carniola, Istria, Moldavia, Transylvania, Wallachia, Lower and Upper Austria, Prussia, Venice, Hungary, Albania, Celta, Crete, Dacia, Dardania, Epirus, Greece, Japodia, Liburnia, Mysia, Pannonia, Romania, Scythia, Baltic Slavonia, Thessaly, Odrysia, Thrace, and Triballia. The real purpose of Vitezović's armorial was to demonstrate his idea of Pan-Croatianism, according to which, all Slavs were the ethnolinguistic Croats and subsequently a Greater Croatia (but no longer the Illyrian Empire of Stefan Dušan) had to be established under the Habsburg sceptre.

However, while Münster's and Ohmučević's Illyrian heraldic manuals were for Vitezović the Croatian, for Žefarović the same Münster's and Ohmučevićs Illyrian coats of arms were the Serbian. Subsequently, Žefarović's Stemmatographia (इmемматографїа) (Vienna, 1741) of coats of arms of all "Serbian" historical-state lands which had to belong to revived Serbian Empire of Stefan Dušan, contributed to the growth of both Serbian national awareness and nationalism. Žefarović presented a triumphant mighty emperor Dušan surrounded by 24 Balkan coats of arms that represented united Serbian Empire (i.e. the Balkan Empire). The message was that all the lands of Dušan's crown (but in fact the whole Balkans) should be politically united into a single (Serbian) state. The

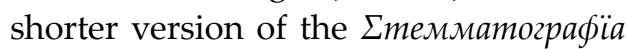
circulated among the Austrian and Ottoman Serbs at the beginning of the $19^{\text {th }}$ century having a strong impact on the idea of restoration of the Serbian mediaeval state during the time of the First Serbian Uprising against the Turks (18031813) and after that as well (Ćorović 1993: 556; Mladićević 1994: 54-59).

The $19^{\text {th }}$ and $20^{\text {th }}$ centuries state and national coats of arms of Croatia and Croats and Serbia and Serbs were modelled according to Vitezović-Žefarović

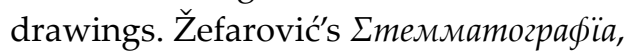
which was based on Vitezović's Stemmatographia..., became one of the most influential ideological and programmatic "lighthouses" for the Serbs in their struggle for the national unification. Vitezović created in his Stemmatographia..., according to the drawing of Mavro Orbin, coat of arms of Bulgaria, and invented completely new coat of arms of Romania. Shortly, Vitezović's "Illyrian" heraldry 
became one of the most influential contributors to the iconography of the Balkan nationalism. Both Vitezović's and Žefarović's heraldic manuscripts were the sources of national identities for the succeeding Croatian and Serbian generations (Banac 1991b; Banac 1993). Žefarovićs collection of "Illyrian" (i.e., the Serbian) coat of arms clearly conveyed the notion that adherence to the Orthodox Christianity made for the Serbs a nationhood and suggesting that the Serbian historical-national task was to unite all the lands of old Illyricum under a single coat of arms of Serbia.

Nevertheless, P. R. Vitezović ideologically mostly influenced development of the Croatian nationalism particularly in the $18^{\text {th }}$ and the $19^{\text {th }}$ centuries. His armorial and ideological Pan-Croatianism was a historical construction and a political program. During these two hundred years, his ideological influence extremely benefited to the Croatian resistance against the Hungarian claims on historical-state rights over the provinces of Croatia, Slavonia and Dalmatia. At the turn of the $19^{\text {th }}$ century Vitezović's writings were in great demand by the Croats and were reprinted in many occasions. During the whole $19^{\text {th }}$ century, Vitezović's Croatia rediviva... was playing a role of "a Bible of the Croatian national policy" and nationalism too (Šišić 1934: 46; Banac 1993). For example, several the most significant and influential $19^{\text {th }}$-century Croatian politicians (some of them the leaders of the Croatian national revival movement - the Illyrian Movement) as Ljudevit Gaj (1809-1872), Ivan Derkos (1808-1834), Janko Drašković (17771856), Ante Starčević (1823-1896) and
Eugen Kvaternik (1825-1871) were rather familiar with Vitezović's work, which crucially influenced their ideology of a Pan-Croatianism. For Gaj, Starčević and Kvaternik ("fathers of the Croatian nation"), the names of the South Slavic nations were only synonyms for the common ethnic name of the Croats (Gaj 1835: 1; Gaj 1965: 299-301; Starčević 1971; Kvaternik 1971). Further, for Derkos and Drašković, the Orthodox Serbs from Croatia, Slavonia, Dalmatia and the Military Border were only ethnolinguistic Croats (Derkos 1832; Drašković 1832).

The insignia (coat of arms) of the Illyrian Movement, invented by $\mathrm{Lj}$. Gaj, was a Morning Star that was inspired by Vitezović's work as well. Ljudevit Gaj still sincerely believed in the Illyrian protohomeland of all Slavs and moreover found "evidence" for this hypothesis in the large number of the Czech, Polish, and Russian coats of arms. For him simply the "Illyrian" (i.e., the Croatian) Morning Star became "only common coat of arms of all our (i.e., the Slavonic-Croatian) tribes and lands" (Gaj 1863, 194). A. Starčević and E. Kvaternik, the founders of the most nationalistic the Croatian Party of Rights, denied the legitimacy of any other term and name of the Balkan Slavs than the "Croat" one. In the other words, all South Slavs were speciums of Croatian gens. In conclusion, the modern Croatian national-political ideology of Gaj, Starčević and Kvaternik was directly derived from Vitezovićs Croatocentric terminology, ideology and viewpoints of the Balkan and world affairs.

P. R. Vitezovićs conception of linguistic nationhood that the language was the pivotal national identifier, significantly 
influenced the South Slavic Romanticist's linguistically based definitions of nationhood. This new approach had a considerable impact to the South Slavic national ideologists especially during the $19^{\text {th }}$ century and the first half of the $20^{\text {th }}$ century. ${ }^{13}$ Ultimately, Vitezović's idea of Lithuanians' (as "Slavic" people) Balkan origin based on ethnolinguistic determination of the nation was shared by famous Lithuanian $19^{\text {th }}-20^{\text {th }}$ century linguist and national worker Jonas Basanavičius, who claimed after many years of scientific investigation and comparison of contemporary Lithuanian and old Thracian languages that the Lithuanian ancestors migrated from the West Balkan province of Thrace (being of ancient Thracians' origin) to the Baltic littoral (Basanavičius 1898, 8-15, 21, 34-35, 74). Still, the Balkan region of Thrace was a part of Vitezovićs Croatia rediviva or united Croatia populated by ethnolinguistic Croats from the time of Antique onward.

It can be given a final conclusion that P. R. Vitezović by following the main idea of the medieval and Renaissance South Slavic writers upon the Slavic matters, who apotheosised Slavism, transformed the message of one of them, Vinko Pribojević, that historical task of the Slavic nation was to rule the world ("ut totius orbis habenas regeret" (Pribojević 1951, 78) into the new futurological anticipation that ethnolinguistic Croats had a historical destiny to rule the globe. Shortly, while Pribojević was speaking in the favour of world Slavic Empire, Vitezović introduced a concept of ethnolinguistic ecumenical Croatian state.

\section{CONCLUSION}

Pavao Ritter Vitezović (1652-1713), an aristocrat of the German origin of the Dalmatian city of Senj, was the first South Slavic national ideologist who extended the Croatian ethnic name not only to all Balkan Slavs, but rather to all Slavs. Using several different mediaeval historical sources upon the Slavic settlement on the Balkan Peninsula and many of the South Slavic literal and historical works that recorded a popular tradition about the Balkan-Illyrian origin of all Slavic people, Vitezović concluded that legendary Slavic progenitors - brothers Czech, Lech and Rus' - should be understood as the persons of the Croat ethnolinguistic origin. Identifying the brothers as the Croats, Vitezović concluded that in fact the entire Slavic population in the world descended from the Croat origin.

During the last stage of the Great Vienna War (1683-1699), between the Christian Alliance against the Ottoman Sultanate, when the struggle between Venice and the Habsburgs for division of the South Slavic lands emerged, Vitezović wrote a memorandum to the Habsburg Emperor in order to refute any Venetian claim on the territory of the "Croatian" historical lands. His work about limites totius Croatiae ("the borders of whole Croatia") demonstrated the borders of a Greater Croatia, which was divided into two parts: Croatia Septemtrionalis (the North Croatia) northward from the Danube River, composed by Bohemia, Moravia, Lusatia, Hungary, Poland, Lithuania and Russia, and Croa- 
tia Meridionalis that was the Balkan Peninsula with Croatia, Slavonia, Dalmatia, Slovenia, Bosnia, Herzegovina, Albania, Epirus, Thessaly, Serbia, Bulgaria, Macedonia and Thrace. The Balkan Croatia was further subdivided into Croatia Alba (the White Croatia) and Croatia Rubea (the Red Croatia). A trans-Danubian Croatia was subdivided into Sarmatia: Poland, Lithuania and Russia, and Venedia: Bohemia, Moravia, and Lusatia. Shortly, the $17^{\text {th }}$-century Croatian usage of the terms "Illyrian" and "Croat" as the synonyms, Vitezović simply extended to all Slavs understanding them as the people of the Croat origin. In the other words, every Slavic nation was seen as specium of the Croatian gens.

The ideology of Pan-Croatianism created by Pavao Ritter Vitezović, who developed the ancient theory upon derivation of all Slavs from the Croats, was a historical construction and a political program as a protest against long-time fragmentation of Croatian historical and ethnic territories, but it was at the same time politics against territorial pretensions on the Croatian historical-ethnic space by the Republic of St. Marco. Finally, Vitezović attempted by his writings to obtain the Habsburg politicalmilitary support for the creation of united or Greater Croatia, i.e. Croatia rediviva. P. R. Vitezović's arguments were both historical and ethnolinguistic that helped him to appropriate a vast territory of Europe, from the Adriatic and Black Sea to Ural and the Baltic Sea, to the Croatdom. Surely, he did not envisage any kind of a united South Slavic state under the name of Yugoslavia or so, but he only designed a united Pan-
Croatian political community paving the ideological road for the Habsburg expansionistic policy at the Balkans and the Central Europe in the coming future.

P. R. Vitezović considered the whole territory of the Polish-Lithuanian Commonwealth as the Croato-Slavic land primarily due to the fact that his knowledge about Poland and Lithuania for the most part came from the writings of proPolish and pro-Slavic authors who saw Lithuania as the Slavic territory. Lithuania at that time was very much Polonized through the spreading of the Polish language and culture. In addition, Vitezovićs apprehension of Lithuania as the Croato-Slavic land came from the facts that the Slavic languages, among the others, were languages of the official correspondence within the Grand Duchy of Lithuania, and what is more important, that majority of Lithuania's population was of the ethnic Slavic origin. Subsequently, according to his Croatocentric doctrine, a "Slavic" Grand Duchy of Lithuania was actually populated by ethnolinguistic Croats and belonged to a united and Greater Croatia rediviva.

Finally, we can agree with Simpson Catherine Anne that for Vitezović the value of the past was equal to that of the present, i.e. the past and the present are juxtaposed and intertwined, and that he occasionally subordinated the present to the past in the light of his national and political ideals (Simpson 1991: 94-107). It explains why in Vitezović's historiographic discourse there is no clear distinction between the past and the present. Also, Blažević Zdenka was right that "both function as argumentative axes around which the functional and trans- 
temporal Croatia as a discursive articulation of Vitezović's worldview is being build" (Blažević 2000: 230). Clearly, Vitezović's "metahistoric" Croatia as "temporalised narrative space" produced by historical discourse" (Velčić 1991: 111) would not be made to fit the geographic boundaries of its contemporary toponym.

\section{Endnotes}

12 For the Serbs, Emperor Dušan was a representative of the national statehoodness, glory and power. At the time of the Ottoman occupation, the Serbian national dream and political ideolo-

gy was framed within the idea to re-establish the Empire of Stefan Dušan (Stanojević 2015: 50-58).

13 See, for instance in (Banac 1983, 448-474; Sotirović 2000,7-24).

\section{Bibliography}

Banac I., 1983: The Confessional "Rule" and the Dubrovnik Exception: The Origins of the "SerbCatholic" Circle in Nineteenth-Century Dalmatia, Slavic Review-American Quaterly of Soviet and East European Studies, № 42 (3). 448-474.

Banac I., 1984: The National Question in Yugoslavia. Origins, History, Politics. Ithaca and London.

Banac I., 1991a: Hrvatsko jezično pitanje. Zagreb.

Banac I., 1991b: Grbovi biljezi identiteta. Zagreb.

Banac I., 1993: The Insignia of Identity: Heraldry and the Growth of National Ideologies Among the South Slavs, Ethnic Studies, vol. 10. 215-237.

Barišić F., 1961: Vizantijski izvori u dalmatinskoj istoriografiji XVI i XVII veka, Zbornik radova Vizantološkog instituta, 7. 227-257.

Basanavičius J., 1898: Lietuviškai Trakiškos Studijos. Shenandoah.

Bazala V., 1954: Stric Grgur i nećak Toma Budislavić, Republika, 10, № 2-3. 255-259.

Bérenger J., 1994: A History of the Habsburg Empire, 1273-1700. London and New York.

Bérenger J., 1997: A History of the Habsburg Empire 1700-1918. London and New York.

Bideleux R., Jeffries I., 1999: A History of Eastern Europe. Crisis and Change. London and New York.

Blažević Z., 2000: Croatia on the Triplex Confinium: Two Approaches, in Roksandić D., Štefanec N., (eds.), 2000: Constructing Border Societies on the Triplex Confinium, International Project Conference Papers 2, "Plan and Practice. How to Construct a Border Society? The Triplex Confinium c. 1700-1750" (Graz, December 9-12, 1998). 221-238. Budapest.

Bogišić R., (ed.), 1970: Pavao Ritter Vitezović, "Plorantis Croatiae saecula duo" in Hrvatski latinisti II: Pisci 17-19 stoljeća, vol. 3 of Pet stoljeća hroatske književnosti, Zagreb.

Bratulić J., (ed.), 1994: Pavao Ritter Vitezović. Izbor iz djela. Zagreb.

Bumblauskas A., 2007: Senosios Lietuvos istorija, 1009-1795. Vilnius.

Bury J. B., 1906: The Treatise De Administrando Imperio, Byzantinische Zeitschrift, XV. 517-577.

Cassio B., 1604: Institutionum linguae illyricae libri duo. Authore Bartholomeo Cassio Curictensi Societatus Iesu. Rome.

Cloke P., Crang Ph., Goodwin M. (eds.) 2009: Introducing Human Geographies, Second edition. London.

Conte F., 1986: Les Slaves. Aux origines, des civilisations d' Europe centrale et orientale (VI-XIII siècles). Paris.

Ćorović V., 1993: Istorija Srba. Beograd.

Cromer M., 1555: De origine et rebus gestis Polonarum. Basel.

Cronia A., 1952: Contributo alla grammatologia serbo-croata, Ricerche slavistiche, 1. 22-37.

Cronia A., 1953: Contributto alle lessicografia del Dictionarum quinque nobilissimaram Europae linguarum di Fausto Veranzio, Ricerche slavistiche, 2.

Cynarski S., 1968: The shape of Sarmatian ideology in Poland, Acta Poloniae Historica, № 19. 6-17.

Darden B. J., 1997: On Zbignew Gołąb, the Homeland of the Slavs, the Indo-Europeans, and the Venetae, Balkanistica, vol. 10. 430-435.

Davies N., 1981: God's Playground: A History of Poland, vol. I, The Origins to 1795. Oxford.

Davies N., 1982: God's Playground: A History of Poland, vol. II, 1795 to the Present. Oxford.

Derkos I., 1832: Genius patriae super dormientibus suis filiis. Zagreb. 
Difnik F., 1986: Povijest Kandijskog rata u Dalmaciji (Historia della guera seguita in Dalmatia tra Ventiani e Turchi dall'anno 1645 sino alla pace e separatione de confini). Split.

Dimić Ž., 1999: Veliki Bečki rat i Karlovački mir 16831699. Hronologija, Beograd, 1999.

Drašković J., 1832: Disertacija iliti razgovor. Zagreb.

Dukat V., 1925: Rječnik Fausta Vrančića, Rad JAZU, 231. 102-136.

Engel J. (redactor), 1979: Großer Historischer Weltatlas. Zweiter Teil. Mittelalter. München.

Fedorowicz J., (ed.): 1982: A Republic of Nobles: Studies in Polish History to 1864. Cambridge.

Fine J., 1994: The Early Medieval Balkans. A Critical Survey from the Sixth to the Late Twelfth Century. Ann Arbor.

Franičević M., 1983: Povijest hrvatske renesansne književnosti. Zagreb.

Fürst-Bjeliš B., 2000: Cartographic Perceptions of the Triplex Confinium and State Power Interests at the Beginning of the $18^{\text {th }}$ century, in Roksandic D., Štefanec N., (eds.), 2000: Constructing Border Societies on the Triplex Confinium, International Project Conference Papers 2, "Plan and Practice. How to Construct a Border Society? The Triplex Confinium c. 1700-1750" (Graz, December 9-12, 1998). 205-220. Budapest.

Gabrić-Bagarić D., 1976: Institutiones linguae illyricae Bartola Kašića i težnje ka standardizaciji jezika, Književni jezik, 1-2. 55-68.

Gabrić-Bagarić D., 1984: Jezik Bartola Kašića. Sarajevo.

Gaj Lj., 1835: Horvatov Szloga y Zjedinjenye, $D a$ nicza Horvatzka, Slavonzka y Dalmatinzka, January $7^{\text {th }}$.

Gaj Lj., 1863: Leljiva, Danica ilirska, June $27^{\text {th }}$.

Gaj Lj., 1965: Horvatov sloga i sjedinjenje, in Hrvatski preporod, vol. I. Zagreb.

Gimbutas M., 1985: Primary and Secondary Homeland of the Indo-Europeans, Journal of IndoEuropean Studies, 13. 185-202.

Gluck W., 1939: Toma Nadalić Budislavić, Pregled, 3, vol. 15, № 183-184. 150-154.

Gołąb Z., 1991: The Origin of the Slavs: A Linguist's View. Columbus.

Golub I., 1976: Juraj Križanić, Hrvat iz OzaljaGeorgius Krisanich Croata-ili Križanićeva ukorjenjenost u zavičaju, Kaj, časopis za kulturu, 9-12. 100-103.

Gortan V., 1958: Šižgorić i Pribojević, Filologija, 2. 149-152.
Gregoire H., 1944-1945: L'origine et le nom des Croates et des Serbes, Byzantion, XVII. 88-118.

Guibernau M., Rex J., (eds.), 1999: The Ethnicity. Nationalism, Multiculturalism and Migration. Oxford.

Hammond, MCMLXXXIV: Historical Atlas of the World. Maplewood.

Hobsbawm E., 2000: Nations and Nationalism since 1870. Programme, Myth, Reality. Cambridge.

Hutchinson J., Smith A. D. (eds.), 1994: Nationalism. Oxford, New York.

Istorija Jugoslavije (group of authors), 1973. Beograd Istorija naroda Jugoslavije (group of authors), 1960: Beograd.

Jelić L. (ed.), 1906a: Fontes Historici Liturgiae Glagolito-Romanae a XII ad XIX saeculum, saec. XIII. Krk.

Jelić L. (ed.), 1906b: Fontes Historici Liturgiae Glagolito-Romanae a XII ad XIX saeculum, saec. XIV. Krk.

Jelić L. (ed.), 1906c: Fontes Historici Liturgiae Glagolito-Romanae a XII ad XIX saeculum, saec. XVIII. Krk.

Johnson L. R., 1996: Central Europe. Enemies, Neighbors, Friends. New York and Oxford.

Kamiński A., 1983: The Szlachta of the Polish-Lithuanian Commonwealth and their government, in Banac I., Bushkovitch P., Yale Concilium, 1983: The Nobility in Russia and Eastern Europe. New Haven.

Kann R. A., 1990: A History of the Habsburg Empire, 1526-1918. Berkeley, Los Angeles, London.

Kapleris I., Meištas A., 2013: Istorijos egzamino gidas: Nauja programa nuo A iki Ž. Vilnius.

Kašić B., 1997: Izabrana štiva. Zagreb.

Kiaupa Z., Kiaupienè J., Kuncevičus A., 2000: The History of Lithuania before 1795. Vilnius.

Klaić N., (ed.), 1972: Izvori za hrvatsku povijest do 1526. godine. Zagreb.

Klaić N., 1971: Povijest Hrvata u srednjem vijeku. Zagreb.

Klaić V., 1914: Život i djela Pavla Rittera Vitezovića (1652-1713). Zagreb.

Kojelavičius (Koialowicz) A. W., 1650/1669 (reprint 1989): Historiae Litvaniae. Dancige, Antverpene.

Kolendić A., 1962: Šest latinskih knjižica štampanih $\mathrm{u}$ Krakovu u čast Dubrovčanina Tome Natalisa Budislavića, Zbornik istorije književnosti, SANU, 3. 211-240.

Kovačević E., 1973: Granice bosanskog pašaluka prema Austriji i Mletačkoj republici po odredbama Karlovačkog mira. Sarajevo.

Križanić J., 1661-1667: Razgowori ob wladatelystwu. Cracow. 
Križanić J., 1859: Gramatično izkazânje ob Rúskom jezíku. Moscow.

Kvaternik E., 1971: Politički spisi. Zagreb.

Laszowski E., 1923: Putovanje Bartula Kašića po Srijemu g. 1612-1618, Hrvatski list, 4, № 264. 2.

Lettere del Cavaliere Ritter: 1700; Biblioteca Universitaria di Bologna, Fondo Marsili, vol. 709, XIX, letter № 2. Bologna.

Ljetopis Popa Dukljanina, 1969: Титоград.

Lučić I., 1986: O kraljevstvu Dalmacije i Hrvatske. Zagreb.

Lucius J., 1668; De regno Dalmatiae et Croatiae libri sex. Amstelodami.

Macan T., 1992: Povijest hrvatskoga naroda. Zagreb.

Maczak A., 1992: Poland, in Porter R. and Teich M. (eds.), 1992: The Renaissance in National Context. Cambridge.

Magocsi R. P., 2002: Historical Atlas of Central Europe, Revised and Expended Edition. Seattle.

Mallory J. P., 1989: In Search of the Indo-Europeans. London.

Marković M., 1987: Prilog poznavanju djela objavljenih u zagrebačkoj tiskari Pavla Rittera Vitezovića, Starine, 60. 71-99. Zagreb.

Marković M., 1993: Descriptio Croatiae. Zagreb.

Marsigli L. F., 1699: Relazione di tutta la Croazia, considerata per il geografico, politico e economico e militare. Bologna.

Matić T., 1950: Bajraktarijev prijevod Orbinijeva "Il regno degli Slavi", Historijski zbornik, 3, № 1-4. 193-197.

Mladićević Z., 1994: Simboli srpske državnosti. Kratak istorijski pregled heraldičkog razvoja u Srba. Kpaгујевац.

Moravcsic G. (ed.), Jenkins R. J. H. (translator), 1949: Constantinus Porphyrogenitus. De Administrando Imperio. Budapest.

Novak G., 1951: Dalmacija i Hvar u Pribojevićevo doba in Pribojević V., O podrijetlu i zgodama Slavena. Zagreb.

Orbin M., 1968: Kraljevstvo Slovena. Beograd.

Orbini M., 1601: Il Regno degli Slavi. Pesaro.

Palmer A., 1970: The Lands Between. A History of East-Central Europe since the Congress of Vienna. London.

Pandžić A., 1988: Pet stoljeća zemljopisnih karata Hrvatske. Zagreb.

Pantelić M., 1965: Glagoljski brevijar popa Mavra iz godine 1460, Slovo, XV-XVI. 94-149.

Pažanin A. (ed.), 1974: Život i djelo Jurja Križanića: Zbornik radova. Zagreb.
Perković Z., 1995: Croatia Rediviva Pavla Rittera Vitezovića, Senjski zbornik, 22. 225-236.

Povest' vremennyh let (translation, introduction and comments by L. Leger), 1884: Paris.

Pribojević V., 1951: De origine successibusque Slavorum. Zagreb.

Radojčić N., 1950: Srpska istorija Mavra Orbinija. Beograd.

Radojčić N., Šišić F., 1929-1930: Letopis Popa Dukljanina, Slavia, vol. VIII, № 5. 158-182.

Rešetar M., 1915: Toma Nadal Budislavić i njegov Collegium Ortodoxum u Dubrovniku, Rad JAZU, 206. 136-141.

Ritter P. E., 1689: Anagrammaton, sive Laurus auxiliatoribus Ungariae liber secundus. Vienna.

Ritter P. E., 1696: Kronika, Aliti szpomen vsega szvieta vikov. Zagreb.

Ritter P. E., 1699: Responsio ad postulata comiti Marsiglio, in Count Marsigli's collection, manuscript volume 103, entitled Documenta rerum Croaticarum et Transylvanicarum in Commisione limitanea collecta, fol. 27r-34r, Biblioteca Universitaria di Bologna, Bologna.

Ritter P. E., 1706: Indigetes Illyricani sive Vitae Sanctorum Illyrici. Zagreb.

Ritter P., 1689: Anagrammaton, Sive Lauras auxiliatoribus Ungariae liber secundus. Vienna.

Ritter P., 1700: Croatia rediviva: Regnante Leopoldo Magno Caesare. Zagreb.

Ritter P., 1701: Stemmatographia, sive Armorum Illyricorum delineatio, descriptio et restitutio. Vienna.

Samalavičius S., 1995: An Outline of Lithuanian History. Vilnius.

Samardžić R., 1983: Veliki vek Dubrovnika. Beograd.

Sančević Z., 1991: Povijesne granice Hrvatske i Bosne prema kartografima of 16 . do 18. stoljeća, Hrvatska revija, vol. I-II. 17-46.

Šapoka A. (ed.), 1936 (reprint 1989): Lietuvos istorija. Kaunas.

Schmaus A., 1953: Vicentius Priboevius, ein Vorläufer des Panslavismus, Jahrbücher für Geschichte Osteuropas, 1. 243-254.

Šidak J., 1972: Počeci političke misli u Hrvata-J. Križanić i P. Ritter Vitezović, Naše teme, XVI/7-8.

Simpson C. A., 1991: Pavao Ritter Vitezović; defining national identity in the baroque age. Manuscript. The School of Slavonic and East European Studies. University of London. London.

Šišić F., 1928: Letopis Popa Dukljanina, Beograd-Zagreb.

Šišić F., 1934: Hrvatska historiografija od XVI do XX stoljeća, Jugoslovenska istoriski časopis, I/1-4. 
Slukan M., 1999: Kartografski izvori za povijest Triplex Confiniuma. Zagreb.

Šmurlo E. J., 1926: Juraj Križanić: Panslavista o missionario, Rivista di letteratura, arte, storia, 1. 3-4.

Šmurlo E. J., 1927: From Križanić to the Slavophils, Slavonic Review, 6, № 17. 321-325.

Sotirović V., 2000: Nineteenth-century ideas of Serbia "linguistic" nationhood and statehood, Slavistica Vilnensis, Kalbotyra, 49 (2). 7-24.

Sotirović V., 2014: The Idea of Pan-Slavic Ethnolinguistic Kinship and Reciprocity in Dalmatia and Croatia, 1477-1683, Politikos mokslu almanachas (Political Science Almanack), 15. 175-187.

Spasić D., Palavestra A., Mrđenović D., 1991: Rodoslovne tablice i grbovi srpskih dinastija i vlastele. Београд.

Stanojević S., 2015: Svi srpski vladari. Biografije srpskih (sa crnogorskim i bosanskim) i pregled hrvatskih vladara. Beograd.

Šrepel M., 1890: Latinski izvor i ocjena Kašićeve gramatike, Rad JAZU, 102. 172-201.

Stančić N., 1985: Hrvatski narodni preporod, 17901848: Hrvatska u vrijeme Ilirskog pokreta. Zagreb.

Starčević A., 1971: Politički spisi. Zagreb.

Štefanić V., 1938: Bellarmino-Komulovićev Kršćanski nauk, Vrela i prinosi, 8. 1-50.

Štefanić V., 1963: Tisuću i sto godina od moravske misije, Slovo, XIII. 5-42.

Stojković M., 1913/1914: Karakteristika života i djelovanja Bartula Kašića iz Paga, Nastavni vjesnik, 22, № 1. 1-9.

Stojković M., 1919: Bartuo Kašić Pažanin, Rad JAZU, 220. 170-263.

Stoye J., 1994: Marsigli's Europe 1680-1730. The Life and Times of Luigi Ferdinando Marsigli, Soldier and Virtuoso. New Haven and London.

Sulimirski T., 1945: Schythian Antiquities in Central Europe, The Antiquaries Journal, XXV. 1-26.

Tadin C., 1903: Elio Lampridio Cerva, Rivista Dalmatica, 3, № 6. 265-278.

Težak S., 1996: Naglasci Jurja Križanića i današnji naglasni odnosi na području Ribnika, Ozalja Dubovca, Filologija, 26. Zagreb.

The Sorbs in Germany (group of authors), 1998. Görlitz.

Vanino M., 1934: Bartul Kašić i književni mu rad, Napredak, kalendar, 23. 123-127.

Vanino M., 1936: O Aleksandru Komuloviću, Napredak, kalendar, 26. 40-54.
Vanino M., 1940: Autobiografija Bartula Kašića, Gradja, 15. 1-144.

Velčić M., 1991: Otisak priče. Zagreb.

Verantius F., 1595: Dictionarium quinque nobilissimarum Europae linguarum, Latinae, Italicae, Germanicae, Dalmatiae \& Ungaricae. Venice.

Vitezović P. R., 1699: Mappa Generalis Regni Croatiae Totius. Limitibus suis Antiquis, videlicet, a Ludovici, Regis Hungariae, Diplomatibus, comprobatis, determinati. 1 : 550000 (drawing in color). $69,4 \times 46,4$ cm. Hrvatski državni arhiv, Kartografska zbirka (Croatian State Archives, Cartographic Collection), D I. Zagreb.

Vitezović P. R., 1706: Offuciae Ioannis Lucii de Regno Dalmatiae et Croatiae Refutate. Zagreb.

Vitezović P. R., 1997: Oživjela Hrvatska. Zagreb.

Vitezovich P., 1696: Kronika, aliti szpomen vszega szvieta vikov. Zagreb.

Vrančić F., 1971: Rječnik pet najuglednijih evropskih jezika. Zagreb.

Wandycz P., 1974: The Lands of Partitioned Poland, 1795-1918. Seattle.

Wandycz P., 1992: The Price of Freedom: a History of East-Central Europe from the Middle Ages to the Present. London.

Wandycz P., 1997: Laisves kaina. Vidurio Rytų Europos istorija nou viduramžiu iki dabartines. Vilnius.

Weigl J. Ch. 1699: Mappa der zu Carlovitz geschlossen und hernach durch zwei gevollmächtige. Comissarios vollzogenen Kaiserlich-Türkischen Grantz-Scheidung, in dem früh jahr 1699. angefangen und nach verfliesung 26. Monaten volendet worden. 1 : 11300 000. 1702. - Copperlate in colour; $290 \times 365 \mathrm{~cm}$. Hrvatski državni arhiv, Kartografska zbirka (Croatian State Archives, Cartographic Collection) A I 12; Muzej hrvatske povijesti, Kartografska zbirka (Museum of Croatian History, Cartographic Collection) 3844, Biblioteka nacionalnog univerziteta, Kartografska zbirka (National University Library, Cartographic Collection) S-JZ-XVIII-14.

Westermann, 1985: Großer Atlas zur Weltgeschichte. Braunschweig.

Zamoyski A., 1987: The Polish Way: a One Thousand Year History of the Poles and their Culture. London.

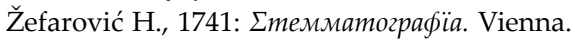

Žic N., 1935: Hrvatske knjižice Aleksandra Komulovića, Vrela i prinosi, 5. 162-181.

Zinkevičius Z., 2013: Lietuviai: Praeities dydybe ir sunykimas. Vilnius. 